\title{
Tamoxifen maculopathy in a male patient
}

\author{
Shreyas Temkar, Amar Pujari, Divya Agarwal, Rohan Chawla
}

Department of Ophthalmology, Dr. Rajendra Prasad Centre for Ophthalmic Sciences, AllMS, New Delhi, India

\section{Correspondence to Dr Amar Pujari, dramarpujari@gmail.com}

Accepted 27 August 2017

\section{DESCRIPTION}

\section{Case description}

A 28-year-old male patient presented with the history of blurring of vision in both the eyes for the past 5 months. The patient was a diagnosed case of desmoid fibromatosis of the right axilla 8 years back. The tumour was initially debulked followed by four cycles of systemic chemotherapy, after which patient was symptom-free for 3 years. The patient noticed an increment in the tumour size, for which he consulted another oncologist. A repeat biopsy was done, which proved the same findings. The patient was started on a combination of tamoxifen $80 \mathrm{mg} /$ day and celecoxib $200 \mathrm{mg}$ /day. $\mathrm{He}$ had received tamoxifen at a cumulative dose of $116 \mathrm{~g}$ over 4 years. Examination in our clinic revealed visual acuity of 20/20 in both eyes with unremarkable anterior chamber findings. Intraocular pressure was 14 and $16 \mathrm{~mm} \mathrm{Hg}$ in right and left eye, respectively. Fundus showed bilateral crystalline refractile deposits in the macula, rest of the retinal and optic disc examination was within normal limits (figure $1 \mathrm{~A}$ and $\mathrm{B}$ ). Red-free images highlighted the presence of intraretinal refractile deposits (figure 1C and D). Spectral domain optical coherence tomography of the retina showed the deposits located in the inner retinal layers with an intact outer retina and pigment epithelium. There was no evidence of intraretinal oedema/cavitation (figure $1 \mathrm{E}$ and F). Humphrey visual field 10-2, colour vision and contrast sensitivity were within normal limits. A diagnosis of tamoxifen retinopathy was made and after consulting the oncologist tamoxifen was stopped. There was gradual improvement in subjective vision over 3 months with maintained visual acuity.

\section{Discussion}

Tamoxifen is a selective oestrogen receptor modulator commonly used as maintenance therapy in female breast carcinomas. Ocular side effects of tamoxifen include retinopathy, cataract, corneal deposits and optic neuropathy. ${ }^{1}$ Retinal manifestations include bilateral refractile crystalline deposits around the perifoveal area with or without associated macular oedema. The cause is not exactly known but could be due to axonal degeneration or inhibition of lipid metabolism leading to deposition of toxic lipiddrug complexes in the lysosomes. The noted duration between the initiations of medication to obvious visual symptoms varies from 2 to 5 years with a prevalence varying from $0.6 \%$ to $3.1 \% .^{23}$ Central visual acuity and colour vision impairment mandate the discontinuation of the medication. In tamoxifen retinopathy cases, retinal imaging may be normal or may show cavitation of the outer retinal layers and partial thickness macular hole. In our case, there was only blurring of vision but the optical coherence tomography did not reveal any form of photoreceptor,
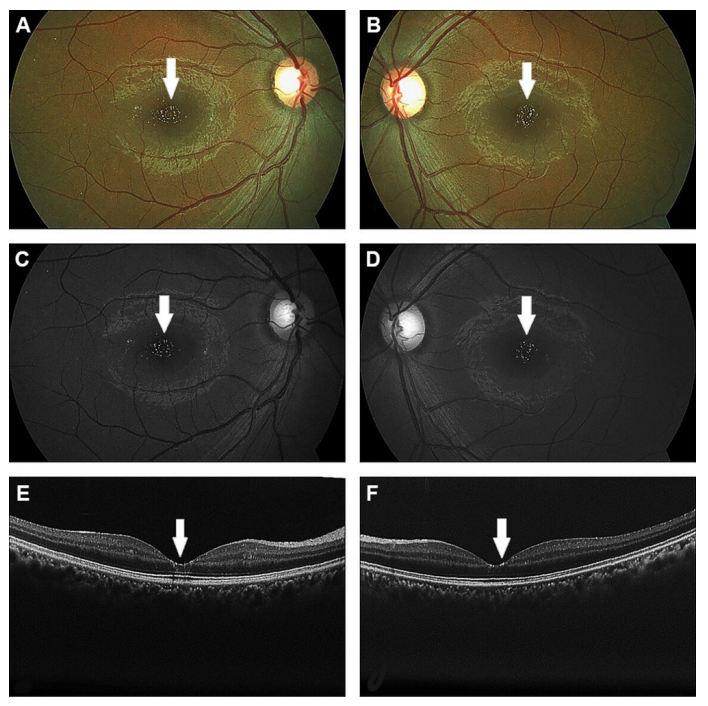

Figure 1 ( $A$ and $B$ ) Right and left eye fundus picture showing refractile white to yellow deposits at the macula. (C and D) Right and left eye red-free imaging revealing refractile deposits at the fovea. ( $E$ and $F$ ) Optical coherence tomography showing deposits mainly in the inner retinal layers without any disruption of the photoreceptor/pigment epithelium.

outer retinal layers disruption or pigment epithelium. Also, visual fields, colour vision and contrast sensitivity was within normal limits. However, the patient in consult with the oncologist was keen on discontinuation of tamoxifen and the patient reported subjective improvement in vision after discontinuation.

There is only one case report of occurrence of tamoxifen retinopathy in a male patient. This 68 -year-old patient was treated for a non-breast carcinoma (unresectable haepatocellular carcinoma) and had received a cumulative dose of $60 \mathrm{~g}$ over 33 months. ${ }^{4}$ In contrast to this case, our patient was younger and received about $116 \mathrm{~g}$ over 4 years. This point probably highlights that the chances of toxicity are higher in older age patients at a lesser cumulative dose. Also, prior retinal toxic chemotherapeutic agents may confound the findings/ manifestations.

Contributors All authors: evaluated the case in detail, after critically analysing the educational value of the case, and together wrote the report.

Competing interests None declared.

Patient consent Obtained.

Provenance and peer review Not commissioned; externally peer reviewed.

(C) BMJ Publishing Group Ltd (unless otherwise stated in the text of the article) 2017. All rights reserved. No commercial use is permitted unless otherwise expressly granted.

\section{REFERENCES}

1. Nayfield SG, Gorin MB. Tamoxifen-associated eye disease. A review. J Clin Oncol 1996;14:1018-26. 
2 Srikantia N, Mukesh S, Krishnaswamy M. Crystalline maculopathy: a rare complication of tamoxifen therapy. J Cancer Res Ther 2010;6:313-5.

3. Lazzaroni F, Scorolli L, Pizzoleo CF, et al. Tamoxifen retinopathy: does it really exist? Graefes Arch Clin Exp Ophthalmol 1998;236:669-73.
4 Yanyali $A C$, Freund $\mathrm{KB}$, Sorenson JA, et al. Tamoxifen retinopathy in a male patient. $A m$ J Ophthalmol 2001;131:386-7.

\section{Learning points}

- Tamoxifen retinopathy in male patients is rare occurrence. Patients on tamoxifen for breast as well as non-breast carcinomas need ocular evaluation at the baseline and at regular intervals even after stoppage of medication.

- Even though there is less evidence to suggest significant visual loss due to retinopathy or cataract, these reversible issues need to be addressed at the earliest to avoid visual comorbidities.

- tnjoy rast sympatnetıc peer review ana rapıa pupıcatıon oт acceptea artıcies

- Access all the published articles

Re-use any of the published material for personal use and teaching without further permission

For information on Institutional Fellowships contact consortiasales@bmjgroup.com

Visit casereports.bmj.com for more articles like this and to become a Fellow 